\title{
An Activity System As A Behavioristic Framework For The Elaboration Of Promotion Techniques
}

\author{
George S. Spais, Athens University of Economics \& Business, Greece
}

\begin{abstract}
In this paper, we intended to examine the possibility to investigate two (2) influential theories: $a$. Activity Theory and $b$. Transformative Learning Theory (TLT) in order to develop a new behavioristic framework that could be introduced to aid the design and analysis of promotion techniques by approaching major promotion events of particular interest and with strategic content, as critical cases. First, we attempted to do this by categorizing sixty-eight (68) identified empirical papers into conceptual categories in accordance to the conceptual and theoretical framework. Second, we provided eleven (11) summary points and ten (10) interpretive claims. Third, we examined three (3) ISP Award Winners as critical cases studies [2002, 2004 and 2006 from three (3) different award categories: (a) "Promotional Communication Point of Purchase", b) "The Most Effective Loyalty Campaign" and c) "Digital Communications"]. This examination gave us valuable information on the potentiality of developing an activity system for the design and analysis of promotion techniques. Thus, the phenomenon studied, through our new proposed micro-model, became more visible with some interesting theoretical and practical implications.
\end{abstract}

Keywords: activity system; critical reflection; behavioristic framework; promotion technique; design and evaluation

\section{INTRODUCTION}

\section{Research aim}

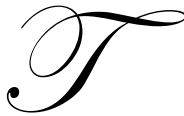

he paper examines the possibility of developing an activity system based on Bedny's representation of Activity Theory incorporating Mezirow's perspective of TLT for Critical Reflection in order to elaborate promotion techniques. A number of scholars have summarized in detail the principles of effective campaign design, implementation, and evaluation (e.g., Randolph \& Viswanath, 2004; Salmon \& Atkin, 2003; Perloff, 2003; Valente, 2001; Atkin, 2001; Rogers \& Storey, 1987). The use of theory is one of them, as it guides the promotional campaigns to be vital to their success (Noar, 2006). The research intention is to examine the possibility to investigate two (2) influential theories: a. Activity Theory and b. Transformative Learning Theory (TLT) in order to develop a new behavioristic framework. The application of such a framework may aid the design and analysis of promotion techniques by approaching major promotion events of particular interest and with strategic content, as critical cases.

The importance of this try arises from the transfer of: i) a psychology theory (Activity Theory); and ii) an adult learning theory (TLT); applied to the promotion management context. Learning theories seems that have gained the appropriate focus in the promotion management literature since the ' $60 \mathrm{~s}$ [see relative theoretical and empirical works of Krugman (1962a, 1962b), Kangun (1968), Krugman \& Hartley (1970), Rothschild, 1981, Rothschild \& Gaidis, 1981, McKee et al., 1992, Chintagunta \& Rao (1996), Ho \& Chong (2003), McKay, (2005), McGregor, 2007)]. Quiet recently, McGregor (2009), in totally accordance with previous research works (in the promotion management and consumer behavior literature); argue that learning theories can provide assumptions also applied to consumer behavior analysis. Quite recently, activity theory seems to gain some focus by marketing 
scholars. According to the recent invitation (2009) of the special issue: "Marketing as Practice" of the Scandinavian Journal of Management, activity theory is characterized as one of the critical perspectives that are warmly welcome in the forthcoming contributions.

Activity theory (a fundamental theory of psychology literature) is an emerging multidisciplinary theory and international community of scientific thought united by the central category of activity - a community reaching far beyond the original background (Coen, 1998). In a broad sense, the activity theory is a philosophical and crossdisciplinary framework for studying different forms of human practices as processes of development. Quite recently, activity theory seems to gain some focus by marketing scholars. According to the recent invitation (2009) of the special issue: "Marketing as Practice" of the Scandinavian Journal of Management, activity theory is characterized as one of the critical perspectives that are warmly welcome in the forthcoming contributions. Blackler and Regan (2009) argued about the application of activity theory to the problem of marketing knowledge and learning offering novel insights how activity is constructed, what tools and resources are available to different participants, and what the inner contradictions of the activity are. Quiet recently in a paper of Ferreira, Zdunczyk \& Simpson (June 2010) that was presented at the 2010 International Conference on Organizational Learning at the Northeastern University, it was underlined the need for an activity theoretical approach to the understanding of marketing knowledge and learning underlining the remarkable insights that activity theory can offer to marketing practice. According to Spais (2010a), Bedny's theoretical perspective of activity theory $(2000 ; 2003)$ is well applicable to the conduct of information behavior research of customers for on-line promotion channels. An activity-theoretical approach to information behavior research can provide a framework for the elaboration of promotion techniques contextual issues, for the discovering of parameters that affect information behavior (Spais, 2010a).

On the other hand, TLT is of high value learning theory offering an interpretation that is uniquely adult, abstract, idealized, and grounded in the nature of human communication (Taylor, 1998). Mezirow's theoretical perspective of TLT $(1978 ; 1990 ; 1991 ; 1998 ; 2000 ; 2003)$ has be proven an emerging multidisciplinary theory, with valuable implications in the promotion management literature, as it is a learning theory of high value, offering an interpretation that is uniquely adult, abstract, idealized, and grounded in the nature of human communication (Spais, 2010b). It seems that Mezirow's critical reflection is well applicable as a framework of promotion metrics' assumptions, if we approach a promotion campaign, as a learning process. A learning process of becoming critically aware of consumers' own tacit assumptions and expectations and those of others and assessing their relevance for making an interpretation of their consuming choice. Therefore, Mezirow's reflection can be considered as a process designed to promote the examination and interpretation of consumers' experience and the promotion of cognitive learning. It is about the process of looking back on the implications of consumers "e actions taken and determining what has been gained, lost, or achieved and connecting these conclusions to future consumers' actions (Spais, 2010b).

One of the implications of this study is that major promotion events of particular interest and with strategic content must be approached as critical cases. These critical cases must be analyzed in terms of a learning process in order for promotion managers to become critically aware of the practical wisdom of promotion events ("promotion management phronesis": a concept in accordance to Flyvbjerg's concept, which contrasts with those of promotion management scientific knowledge "episteme" and promotion management technical expertise "techne"). Therefore, Flyvbjerg's "phronesis" raises the question whether this concept and the related construct actually add anything to promotion assumptions and best practices for promotion managers (Spais, 2010c). This interesting "marriage" in a new behavioristic framework for the elaboration of promotion techniques is what critically we want to investigate in this paper.

\section{Assumptions Of The Paper}

A. The development of an activity system based on Bedny's representation of Activity Theory incorporating Mezirow's perspective of TLT for Critical Reflection for the elaboration of promotion techniques seems that it can become a new promising theoretical micro-model framework. A new conceptual foundation of consumer responses in the promotion management literature that can suggest determinants of designing and analyzing promotion techniques by approaching major promotion events of particular interest and with strategic content, as critical cases. 
B. Mezirow's critical reflection can be proven quiet valuable to the proposed behavioristic framework by considering each promotion campaign, as a learning process. Mezirow's reflection in the promotion management context can be considered as a process designed to promote the examination and interpretation of consumers' experience and the promotion of cognitive learning.

\section{Conceptual Model- Reasoning The Focus Of The Paper}

This study offers a perspective of incorporating Mezirow's critical reflection in an activity system, as a new behavioristic framework (a new micromodel), which can be used to aid the design and analysis of promotion techniques by approaching major promotion events of particular interest and with strategic content, as critical cases. In accordance to the principles of effective promotion campaign design, implementation, and evaluation, the incorporation of Mezirow's critical reflection in Bedny's representation of activity system can serve as a conceptual foundation that can suggest important determinants (see Figure 1).

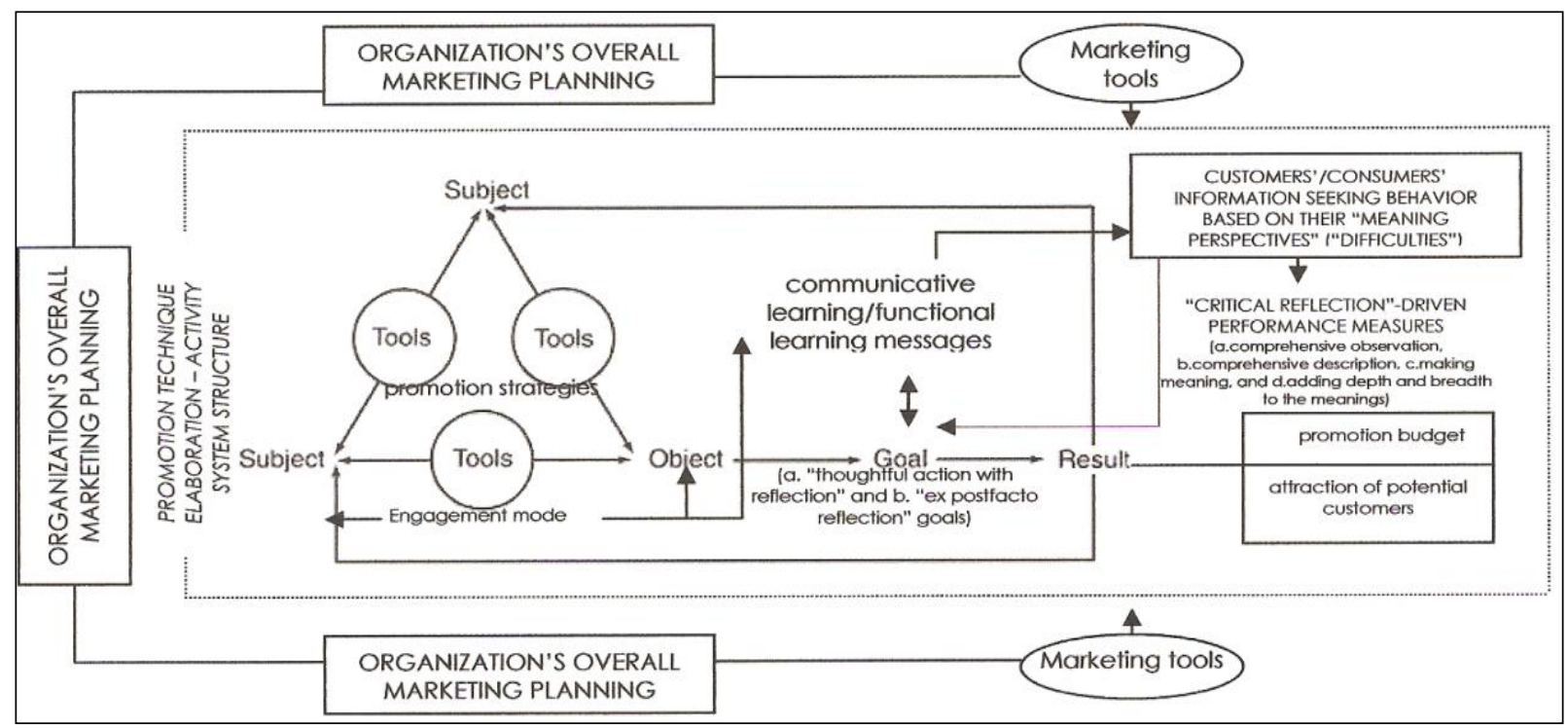

Figure 1: The proposed activity system for the design and analysis of promotion techniques based on Spais (2010a)

The knowledge of the proposed activity system for the elaboration of promotion techniques, guides the collection and the analysis of the data. Based on the above, we present the research themes that we aim to investigate in this paper.

\section{Research Question}

Can the above activity system be introduced as a behavioristic framework for promotion managers to elaborate promotion techniques for long-term promotion campaigns that include major promotion events of particular interest and with strategic content?

\section{Previous Research Of Activity Theory In The Promotion Management Context}

Spais (2010a) examined the possibility of an extension of Bedny's perspective of 'activity' theory as a framework for the elaboration of new online promotion channels, such as the search engines. This conceptualization was approached as a framework for Search Engine Optimization (SEO) contextual issues, which could be used to aid the design and analysis of the SEO promotion technique investigations. Based on the analysis of the main notions of activity theory Uden, Valders and Pastor's work (2008) defined web application's requirements. According to the authors, activity theory constitutes a valuable tool for analyzing web applications and provides the 
web application developers with a model that allows them to properly specify navigational and organizational requirements. Xu (2007) proposed an integrated framework, based on activity theory, with a focus on interactive information retrieval behavior. Suh, Couchman, Park and Hasan (2003) demonstrated a conceptual model of webmediated communication (WMC). The authors employed activity theory to investigate elements and structure of communication activity via a web site. In this study, the term "web-mediated marketing communications" was defined as the firm's use of a web site for marketing purposes.

\section{Originality Of The Paper - Contribution To Knowledge}

The development of an activity system based on Bedny's representation of Activity Theory incorporating Mezirow's perspective of TLT for Critical Reflection for the elaboration of promotion techniques seems that it can become a new promising theoretical micro-model framework. A new theoretical micro-model framework of consumer responses in the promotion management literature (Spais, 2010a; 2010b). Many micromodels of audiences' responses are examined in empirical works of the promotion and media campaigns' literature (see also Noar, 2006 for an interesting review of the decade 1996-2005) such as: a) hierarchy-of-effects model (e.g. Craig, Bauman \& Reger-Nash, 2010; Vaughan \& Rogers, 2000; Barry \& Howard, 1990), b) cognitive dissonance (e.g. Hwang, 2010; Hansen et al., 2009; Soutar \& Sweeney, 2003; Festinger, 1957), c) consumer information processing theory (e.g. Davies \& Cline, 2005; Doniger et al., 2001; Bettman, 1979), d) diffusion of innovations theory (e.g. Dearing 2008; Smith, 2007; Daugherty \& Reece, 2002; Oldenburg, Hardcastle \& Kok, 1997; Kotler and Roberto, 1989; Rogers, 1983), e) theory of reasoned action (e.g. Cohen, Shumate \& Gold, 2007; Stead et al., 2005; BoothButterfield \& Reger, 2004) f) theory of planned behavior (e.g. Baker \& White, 2010; Pelling \& White, 2009; Tan \& Uncles, 2008; Lin, Lin \& Wu, 2008), g) elaboration likelihood model (e.g. Berry et al., 2009; Reger et al., 2002), h) extended parallel process model (e.g. Green and Witte, 2006; Roberto et al., 2000; Witte et al., 1998), i) media practice model (e.g. Bobkowski, 2009; Pardun, L'Engle \& Brown, 2005; Brown, Steele \& Walsh-Childers, 2002), i) social norms theory (e.g. Pechmann \& Wang, 2010; Cameron \& Campo, 2006; Fabiano et al., 2003; Toombs \& Hamilton, 2002), $k$ ) social integration model (e.g. Beaudoin, 2007; Thorson \& Beaudoin, 2004), l) social learning theory/social cognitive theory (e.g. Merskin, 2008; Cohen, Shumate \& Gold, 2007; Brekke \& Rege, 2007; Atkin, Hocking \& Block, 1984), $\underline{m}$ ) change model (e.g. Maddock, Silbanuz and Rger_Nash, 2008; McAlister et al., 2004; ). Critical reflection seems that it remains unexplored (Spais, 2010b).

There is a significant literature regarding to different TLT constructs in the promotion management literature, such as: i) "learning" [McGregor (2009), McGregor (2007), McKay, (2005), O'Sullivan (2003), Ho \& Chong (2003), Chintagunta \& Rao (1996), Knouse (1986), Rothschild (1981), Rothshild \& Gaidis (1981), Smallwood \& Conlisk (1979), Schmalensee (1978), Krugman \& Hartley (1970), Kangun (1968), Krugman (1962a), Krugman (1962b)], ii) "questioning consumers' experience" ("critical reflection") [Frambach, Roest \& Krishnan (2007), Fitzsimons, Nunes \& Williams (2007), Andreu, Bigne, Chumpitaz \& Swaen (2006), Ofir \& Simonson (2001), Wooten and Reed II (1998), Johnson \& Mathews (1997), Park, Feick \& Mothersbaugh, (1992), Thompson, Locander \& Pollio (1989), Deighton \& Schindler (1988), Ölander (1977)] and iii) "difficulties" subjected by the subjective nature of emotions involved in each of consumers' experience ("difficulties of critical reflection") [Kwortnik \& Ross (2007), Desmet \& Hekkert (2007), Holbrook (2006), Andrews, Drennan \& Bennett (2005), Hoch (2002), Richins (1997)]. No study, until now, has offered the perspective of incorporating Mezirow's critical reflection in an activity system, as a new behavioristic framework (a new micromodel), which can be used to aid the design and analysis of promotion techniques by approaching major promotion events of particular interest and with strategic content, as critical cases.

Although there is a significant literature for activity theory (mostly from the field of information research), activity system constructs such as "subject", "object" and "goal statement", are relatively unexplored (Spais, 2010a). According to Noar (2006), theory can serve as a conceptual foundation for a campaign and can suggest important determinants upon which promotion campaign messages might focus. In extension, we believe that a conceptual foundation can also suggest determinants of designing and analyzing promotion techniques. We strongly believe that critical reflection should be considered as the most significant promotion management goal that determines the design and analysis of the promotion techniques in order to influence consumers' future actions fostering a "learning environment". 


\section{THEORETICAL FRAMEWORK - ASSUMPTIONS OF THE TWO THEORIES}

In this section, we will present the assumptions of the two leading theoretical perspectives: a. Bedny's representation of Activity Theory (Bedny, Seglin and Meister, 2000) and b. Mezirow's critical reflection representation of Transformative Learning Theory [Mezirow (1991), (1998), (2000), (2003) and Kitchener \& King (1990)].

Table 1: Examining the assumptions of the two theoretical perspectives from the two theories

\begin{tabular}{|c|c|}
\hline A. Bedny's assumptions: & B. Mezirow's assumptions: \\
\hline $\begin{array}{l}\text { 1. An activity is motivated towards transforming an object into } \\
\text { a result. Activities have an object and are defined by that } \\
\text { object, while transformation of the object motivates the } \\
\text { existence of the activity. } \\
\text { 2. There is no activity without a motive; 'unmotivated' activity } \\
\text { is not an activity that has no motive, but it is the one with a } \\
\text { subjectively and objectively hidden motive. } \\
\text { 3. A subject is a person that undertakes an activity, either } \\
\text { individually or as part of a team. Subjects are people in } \\
\text { different roles that transform materials and use information. } \\
\text { Subjects are part of a collective effort. } \\
\text { 4. Tools shape the way in which people interact with reality. } \\
\text { Tools are shaped by other's experience with regard to their try } \\
\text { to solve similar problems, and, thus, try to make the tool more } \\
\text { useful or efficient. The use of tools is an evolutionary capture } \\
\text { and use of knowledge that influences not only external } \\
\text { behavior, but also the mental functioning of the individual and } \\
\text { future tool design. Tools provide the subject with enhanced } \\
\text { capabilities. Besides, they restrict interaction to be from the } \\
\text { perspective of the particular tool being used. } \\
5 \text {. A goal directed system should be adopted where cognition, } \\
\text { behavior, and motivation are integrated and organized by a } \\
\text { mechanism of self-regulation towards achieving a conscious } \\
\text { goal. } \\
6 \text {. The result of an activity may or may not be one that } \\
\text { accomplishes the object, if there is one in the representation. }\end{array}$ & $\begin{array}{l}\text { 1. Individuals have their own expectations about the world, } \\
\text { framed within their own cultural backgrounds and } \\
\text { presuppositions, which directly influence the meaning derived } \\
\text { from personal experiences. } \\
\text { 2. Transformative learning theory addressed the revision of } \\
\text { meaning structure (changing the perspective of an individual). } \\
\text { 3. Perspective transformation explains the process of how } \\
\text { adults revise their meaning structures. According to Mezirow, } \\
\text { experience, critical reflection on experience and rational } \\
\text { discourse with others are the key features for changing an } \\
\text { individual's meaning structure. } \\
\text { 4. Experience provides the grist for critical reflection. } \\
\text { 5. The individual and others then subject these meanings to } \\
\text { scrutiny. } \\
\text { 6. Critical reflection involves questioning the integrity of an } \\
\text { individual's assumptions and beliefs, which results in } \\
\text { transformation or change in an individual's perspective. } \\
\text { 7. Transformative learning prerequisites experiences and } \\
\text { beliefs into the time and is described by Mezirow as having ten } \\
\text { (10) stages that progress from a characteristic "disorienting } \\
\text { dilemma" that uses an experience of imbalance in an } \\
\text { individual's life as an opportunity for considering new } \\
\text { perspectives. From this new vantage point, the individual may } \\
\text { continue to examine unfamiliar views, critically reflect and } \\
\text { evaluate them, test and explore new perspectives, make } \\
\text { choices as to whether to adopt those positions and finally } \\
\text { reintegrate these new perspectives. }\end{array}$ \\
\hline
\end{tabular}

\section{LITERATURE REVIEW} Process And Categorizing The Concepts Linked To "Activity System For The Design And Analysis Of
Promotion Techniques"

The literature review process is developed through three (3) stages: a) bibliography collection and search strategy (for the needs of the search, we adopt: a. "briefsearch" and "citation pearl growing" search strategies); b) Based on the first stage, an extension of the literature review will be achieved progressively and c) abstractive synopsis and homogenization based on the key words, allow us to categorize the research works. The use of G.I.S.T. principle provides us a safe guide in order to identify broader groups arisen from the research question. For the investigation of the research question, we categorize the concepts linked to the basic concept of the "activity system for the design and analysis of promotion techniques" (as presented in Table 2). At the next subsections, we present the research activity for each conceptual category, the classification of the empirical evidence in chronological order and the summary of the literature findings. 


\section{Research Activity For Each Conceptual Category}

In this subsection, we present the relative research activity for each conceptual category of the examined concept of "activity system for the design and analysis of promotion techniques", according to the categorization of the above subsection. In the following table (see Table 2) we present the research works (presented in international academic journals and proceedings of international academic conferences), based on the keywords of the conceptual mapping and the G.I.S.T. literature review principle. The literature review is based on an initial judgmental sample of eighty (80) published research works (selected at the first stage of the literature review, using the above conceptual categories as keywords). After the scanning, we reach at one to the following sixty-eight (68) research works (see Table 2), as an indicative research activity for the basic concept of this study. The search and process stage took place from August 30 to November 10, 2010. The focus of the sixty-eight (68) published research works is presented in Table 2.

Table 2: The research activity for each of the conceptual categories of "Activity System for the Design and Analysis of Promotion Techniques"

\begin{tabular}{|c|c|c|c|}
\hline \multicolumn{2}{|c|}{$\begin{array}{l}\text { Categories of } \\
\text { Concepts Linked to } \\
\text { "Activity System } \\
\text { for the Design and } \\
\text { Analysis of } \\
\text { Promotion } \\
\text { Techniques" }\end{array}$} & Research Works & $N=68$ \\
\hline A. & Activity & $\begin{array}{l}\text { Ferreira, Zdunczyk \& Simpson (2010); Tam \& Melles (2010); Spais (2010a); Blackler \& Regan } \\
\text { (2009); Young (2009); Banna, AlKayid, Hasan \& Meloche (2009); Wilson (2008); O’Brien \& } \\
\text { Toms (2007); Xu (2007); McCullough (2007); Wilson (2006); Barr, Noble, Biddle \& Khaled } \\
\text { (2006); Bertelsen \& Godsk (2004); Suh, Couchman, Park \& Hasan (2003); Uden \& Willis } \\
\text { (2001); }\end{array}$ & 15 \\
\hline B. & Subject & Lutze (2008); Christ (2007) & 2 \\
\hline C. & Object & Yucha \& Sasi (2005); Montgomery, Sharafi \& Hedman (2004) & 2 \\
\hline D. & Tool & $\begin{array}{l}\text { Tam \& Melles (2010); Green (2003); Fjed, Lauche, Bichsel, Voorhorst, Krueger \& Rauterberg } \\
(2002)\end{array}$ & 3 \\
\hline E. & Goal & McMahon \& Griffy-Brown (2009); Mursu, Luukkonen, Toivanen \& Korpela (2007) & 2 \\
\hline F. & Result & $\begin{array}{l}\text { Murphy \& Kielgast (2008); Kennedy \& Kennedy (2008); Gadish (2008); Rimbach, Dannenberg } \\
\text { \& Bleimann (2007); Thelwall (2001) }\end{array}$ & 5 \\
\hline G. & $\begin{array}{c}\text { Functional } \\
\text { learning }\end{array}$ & Chandran \& Morwitz (2005); Hui \& Bateson (1991); Krugman \& Hartley (1970) & 3 \\
\hline H. & $\begin{array}{c}\text { Communicative } \\
\text { learning }\end{array}$ & Cherrier \& Lego Munoz (2007); Brown, Holmes \& Pan (2005) & 2 \\
\hline I. & $\begin{array}{l}\text { Critical } \\
\text { reflection }\end{array}$ & $\begin{array}{l}\text { Spais (2010b); Yoon, Cole \& Lee (2009); Cowley (2008); Bertilsson (2007); Frambach, Roest } \\
\& \text { Krishnan (2007); Fitzsimons, Nunes \& Williams (2007); Andreu, Bigne, Chumpitaz \& } \\
\text { Swaen (2006); Ahuvia (2005); Novemsky \& Ratner (2003); Mooy \& Robben (2002); Ofir \& } \\
\text { Simonson (2001); Johnson \& Mathews (1997); Park, Feick \& Mothersbaugh (1992); } \\
\text { Thompson, Locander \& Pollio (1989); Deighton \& Schindler (1988); Childers \& Houston } \\
\text { (1984); Ölander (1977) }\end{array}$ & 17 \\
\hline $\mathbf{J}$. & $\begin{array}{l}\text { Revision of } \\
\text { meaning } \\
\text { structure }\end{array}$ & $\begin{array}{l}\text { Arsel \& Thompson (2010); Berger \& Heath (2008); Berger \& Heath (2007); Vida (2007); Penz } \\
\text { (2006); Allen (2002); Bigne, Aldas-Manzano, Kuster \& Vila (2002); Kozinets (2001); Clarke, } \\
\text { Kell, Schmidt \& Vignali (1998); Thompson \& Haytko (1997) }\end{array}$ & 10 \\
\hline K. & Difficulties & $\begin{array}{l}\text { Kim, Natter \& Spann (2009); Kwortnik \& Ross (2007); Desmet \& Hekkert (2007); Holbrook } \\
\text { (2006); Andrews, Drennan \& Bennett (2005); Petrova \& Cialdini (2005); Hoch (2002); } \\
\text { McLarney \& Chung (1999); Richins (1997) }\end{array}$ & 9 \\
\hline
\end{tabular}

\section{Classifying Empirical Evidence According To Chronological Order}

Based on the above table (see Table 2) we present the chronological order of the sixty-eight (68) research works. The activity system for the design and analysis of promotion techniques though the two underlined 
theoretical perspectives is a very new research field in the promotion management literature. The chronological order of the above conceptual categories allows us to identify: i) the level of research activity; ii) the research priorities for each period; iii) the research gaps as also; iv) valuable research directions and suggestions for further research. We classify the above research in to eleven (11) categories according to the conceptual categories of the "activity system for the design and analysis of promotion techniques". Diagram 1 presents the chronological order of the research activity for each of the conceptual categories, with some interesting remarks.

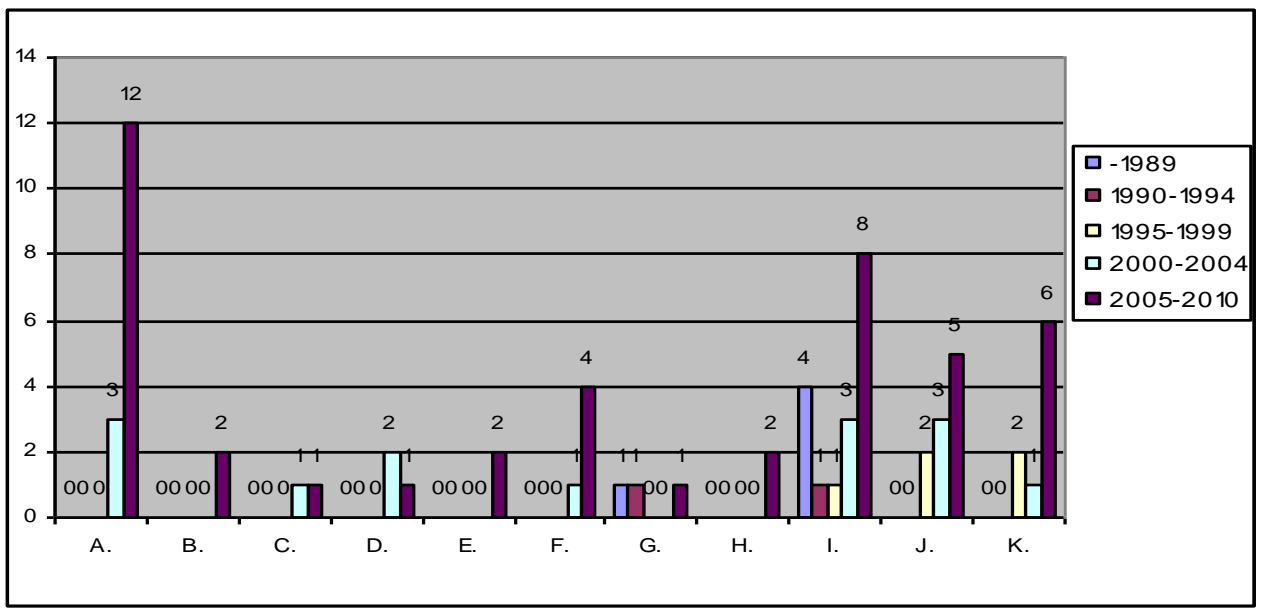

Diagram 1: Research activity for each of the conceptual categories of "Activity System for the Design and Analysis of Promotion Techniques" presented in a chronological order (from 1989-2010)

\section{Remarks Based On The Above Diagram}

- $\quad$ There is an explosion of the research activity of many conceptual categories of the "activity system for the design and analysis of promotion techniques" the last five years (2005-2010).

- $\quad$ Activity theory seems that gains the research interest by marketing scholars the last five years.

- $\quad$ There is a very significant increase of the research activity for critical reflection the last five years. Critical reflection's constructs such as "revision of meaning structure" and "difficulties" seem that gain the focus by marketing scholars in comparison with other critical reflection's constructs.

- Although activity system elements of "subject", "object", "tool" and "goal" gain the research interest over the last five years, the research activity is relatively low.

- Critical reflection's constructs such as "functional learning" and "communicative learning" is not gaining the appropriate focus, as the research activity is kept at a very low level, the last years.

\section{Summary Of The Literature Review Findings}

We summarize the findings as follows:

- $\quad$ Regarding to "activity": it seems that activity theory constitutes an analytical framework for the activities of a marketing department. Activity theory it seems that can guide the promotional campaigns to be vital to their success. It seems that activity theory can serve as a conceptual foundation for a campaign and can suggest important determinants upon which promotion campaign messages might focus. Evidences show us that a holistic approach of activities enables the organizations to create value, only if activity system designers consider design elements, such as content, structure and governance, and design themes, such as efficiency, novelty and complementaries, as sources of activity system's value creation for customers and consumers. 
- Regarding to "subject", "object", "tool" and "goal”: it seem that gained the research interest over the last five years, the research activity is relatively low. The available empirical evidence show that activity theory shapes the design of promotions' philosophy, as it is based on the concept of tools mediating between subjects and objects, which are influenced by individual's creative interaction with his/her surroundings and the increasingly sophisticated promotion techniques. The empirical evidences show us that there is a tendency of increasingly sophisticated promotion techniques to achieve marketing goals, as they play a crucial role in marketing planning but they need to be understood and addressed under a model. Evidences also underline the clear impact of an organized marketing process on goal statement and a need for goals to be adapted with regard to messages that communicate values. Evidences also show us the significance of the goal statement of an activity, with regard to the: a) understanding of the nature of the activity, b) description of the goal statement, and c) planning for the transformation to the goal statement.

- Regarding to "result": it seems that promotion techniques are crucial tactical and strategic marketing tools and they must be aligned with an organization's overall marketing planning. In addition, in terms of performance measurement of promotion techniques, there is a tendency to be correlated with the level of an organization's marketing budgets. Evidences also support that different promotion strategies have to be adopted in order to attract effectively potential consumers and customers as a marketing-driven result.

- Regarding to "functional learning": It seems that passive learning is typically effortless responsive to animated stimuli, amenable to artificial aid to relaxation and characterized by an absence of resistance to what is learned, thus opening up possibilities that, depending on one's point of view, one may welcome or deplore. Learning should be conceived as active and purposive behavior, involving motivation, practice and achievement. It is evidenced that the degree of consumer's-learner's perceived control influences cognitions and intentions, a variable in mediating the consumer's emotional and behavioral responses to the physical environment and the contact personnel of an organization.

- Regarding to "communicative learning": It seems that there is a need for marketers to understand consumers' authentic feelings, in order to create a way for consumers to seek redress therefore reducing incidents of undesirable behaviors. Some of the significant intense emotions of consumers that result negative consumer behavior directed at the marketer are: a) powerlessness, b) betrayal, c) suffering and d) feeling cheated.

- Regarding to “critical reflection": It seems that consumer experiences can be effectively analyzed through existential-phenomenology, using metaphors and asking intention questions about engaging new behaviors. It is strongly evidenced that consumer experiences are adapted based on context issues such as individual characteristics, task demands, emotions, retail environment and satisfaction, which are related to consumers' decision-making processes, are strongly influenced by: a) products'/services' communication messages and $b$ ) the adoption of the appropriate promotion techniques that can encourage the consumer to look back at an product or consumption experience in order a new behavior to be engaged.

- Regarding to "revision of meaning structure": It seems that the meaning structure of consumers determined by a broad set of predispositions from socio-economic and socio-psychological assumptions, shape consumers' expectations which in turns influence the selection and the design of the promotion technique.

- Regarding to “difficulties": It seems that consumers' emotions involved in consumption experiences and in all levels of product experiences (aesthetic, meaning and emotional) have a strong impact on consumers' choices and product preferences but product experience or consumption experience seems to seduce consumers into believing that they learn more than is actually so. It seems that it is quiet critical in the choice and design of a promotion techniques. Many promotion managers approach such experiences because of a formal education process and consequently it seems that experience supports a pseudodiagnosticity that draws the consumer in as a willing partner in the seduction, which is not true.

Based on the theoretical framework of the present study, we can interpret the above findings as follows:

- $\quad$ Promotion techniques are motivated towards transforming an object into a marketing result.

- $\quad$ There is no promotion activity without a marketing motive. 
- $\quad$ Promotion techniques shape the way in which customers act. Promotion techniques are shaped by consumers' experience regarding their try to solve information seeking problems, and, thus, try to make the promotion techniques more useful or efficient.

- $\quad$ The use of promotion techniques is an evolutionary capture and use of knowledge that influences not only consumers' behavior, but also the mental functioning of the individual and future technique design, as individual's reaction and the increasingly sophistication of design and analysis of promotion techniques influence it.

- A promotion goal directed system should be adopted where consumers' cognition, behavior, and motivation are integrated and organized by a mechanism of self-regulation toward achieving a conscious goal through the communication of values.

- $\quad$ The marketing result of promotion activities may be the one that accomplishes the object.

- Promotion techniques based on the notion of critical reflection is one of the prerequisites for changing consumers' meaning structure.

- $\quad$ Promotion techniques based on the notion of critical reflection must involve questioning the integrity of a consumer's assumptions and beliefs, which results in transformation or changes in a consumer's perspective or engagement of a new behavior.

- Promotion techniques based on the notion of critical reflection must influence consumers' expectations about the solutions offered by an organization framed within their own cultural backgrounds and presuppositions, which directly influence the meaning derived from personal consumption and product experiences.

- $\quad$ Promotion techniques based on the notion of critical reflection must encourage the consumer to examine unfamiliar views, critically reflect and evaluate them, test and explore new perspectives, make choices as to whether to adopt those positions and finally reintegrate these new perspectives.

As a conclusion to this section, the findings arisen from: a) the study of international empirical evidence and b) their interpretation (based on the theoretical framework) leaded us to an initial understanding of how two influential theories can contribute to the development of a new behavioristic framework, which can be used to aid the design and analysis of promotion techniques. Therefore, the phenomenon studied becomes more visible.

\section{METHODOLOGY}

\section{Research Method And Unit Of Analysis}

The investigation of an activity system as a behavioristic framework based on Bedny's representation of Activity Theory and incorporating Mezirow's perspective for Critical Reflection for the elaboration of promotion techniques is a non-researched area. In order to determine Bedny's and Mezirow's theoretical perspectives of the proposed activity system's constructs for the elaboration of promotion techniques and their relationship, it is incumbent upon marketing scholars to take the above perspective, which allows these issues to be arisen. The use of the case study is considered to be of high value in our analysis because in the empirical studies none of promotion phenomena are very well understood (Cutler, 2004). The research method of case study is introduced in order to reveal very new constructs and to attempt to establish an initial understanding of the constructs and their relationship with other constructs (Yin, 1994). Human activity is the basic unit of analysis in activity theory. Activity theory incorporates notions of understanding such as mediation, motivation and culture.

\section{Selection Of A Critical Case And Determination Of Data Gathering And Analysis Techniques.}

Selecting the critical case: Flyvbjerg (2006) suggested since 1991 the concept of the critical case, where a case of particular interest and strategic content in relation to the investigated research themes are presented. We believe that the three (3) ISP Award Winners critical cases studies [2002, 2004 and 2006 from three (3) different award categories: (a) "Promotional Communication Point of Purchase", b) "The Most Effective Loyalty Campaign" and c) "Digital Communications"] available at the on-line Promotional Case Study Library of the Institute of Promotional Marketing/IPM, (former Institute of Sales Promotion, UK) will give us valuable information. Information on the potentiality of developing an activity system for the design and analysis of promotion techniques and, thus, the phenomenon studied can become more visible, as Stake (1994) argued. The different aspects of a context, from 
which a particular problem situation originates, can become increasingly visible and more accessible for a promotion management researcher. We consider the critical cases presented by the Institute of Promotional Marketing (UK) because the Institute is the leading institute of promotional marketing in UK and Europe with 300 members, drawn from brand owners, marketing agencies and service partners, and its mission is to protect, promote and progress effective promotional marketing across all media channels. The institute represents the interests of promoters, agencies and service partners engaged in promotional marketing. The institute is recognized (globally) by the promotional marketing society for the "IPM Awards" program. The program is the basis for the highly regarded Promotional Case Study Library.

Methodology for gathering the data from the critical case: Based on Uden, Valders and Pastor's work (2008), we have adopted the following methodology in order to gather the data in the critical cases presented by the Institute of Promotional Marketing:

1. Clarification of the purpose(s) of the activity system. Clarification of the motives and goals of the activity system is very important. The purposes of this step are: a) to understand the context within which activities occur, and $b$ ) to reach a thorough understanding of the motivations for the activity being modeled and any interpretations of perceived contradictions.

2. Analysis of the activity system and production of the activity system. This step involves an in-depth definition of the components of the given activity, namely, the subject, object, tool, goal and result.

3. Analysis of the activity structure. This step involves decomposing each activity into actions and operations. An important key process here is to analyze the activity structure (all of the activities that engage the subject) that defines the purpose(s) of the activity system. The conceptual categories of Table 2 will lead the description of actions and operations of the activity structure.

Evaluation and analysis of the data. The data of activity structure analyses resulted from the performance of three IPM's critical case studies analyses from August 2 to August 23, 2010 [in accordance with the methodological guidelines for qualitative content analysis in case study research of Kohlbacher (2006)] utilizing the conceptual categories of "activity system for the design and analysis of promotion techniques", available at: http://www.theipm.org.uk/case_studies/Introduction_to_case_study_library/free_examples.aspx (August 1, 2010). The analysis of the data, as an activity system, has led us to the following table (Table 3), which summarizes the findings:

Table 4: Summary of data analysis of the three (3) critical cases based on the activity system structure for the design and analysis of promotion techniques

Case - Promotional message: "Hunk - The flash easy cleaning revolution” (Procter \& Gamble)

Sector: Household, Fashion \& Beauty

Promotion objectives: awareness, trial

Promotion strategy: To target savvy mums who want to keep their homes clean as effortlessly as possible without taking shortcuts. To communicate with the target audience via the internet identified as one of their regular leisure time activities. To make best use of the online medium with a product demonstration that not only educates consumers but also actively involves them in a fun and engaging 'virtual trial'. To raise awareness of the site with an e-mail campaign and incentivise traffic by rewarding participation

Promotion techniques: 1. prize promotion

Agency: ARC Worldwide

Awards: ISP Gold Award winner 2006 - Digital Communications

ISP Service Partner Recognition Award 2006 - FLAWLESS

Description of the promotion technique: Visitors to the Flash Hunk site were able to watch the cheeky home help demonstrate how easily the products could be used. They could also control him by typing in what they wanted to see cleaned, e.g. hob, floor. Each time they requested an activity that used a new product they were awarded a medal. A prize draw was held every Friday for the 20 -week promotional period. The first 250 participants, randomly selected by an independent person each received $£ 2$ worth of leisure vouchers to be used at Costa Coffee. All registrations received in July 2005 were entered into an additional prize draw. The first 500, randomly selected by an independent person, were awarded a Flash Dustmaster Extend and Reach worth $£ 4.48$. The Grand Prize Draw held on October 10 included all registrations received during the promotional period. The first entry, randomly selected by an independent person, received $£ 10,000$. A list of winners was available on the website. Winners were notified within 7 working days of each draw and prizes dispatched within 28 days. 
Table 4: continued

\begin{tabular}{|c|c|c|c|c|c|}
\hline subject & tool & object & goal & result & $\begin{array}{c}\text { Comments } \\
\text { ("Meaning } \\
\text { Perspectives" \& } \\
\text { "Difficulties") }\end{array}$ \\
\hline $\begin{array}{c}\text { ARC } \\
\text { Worldwide }\end{array}$ & 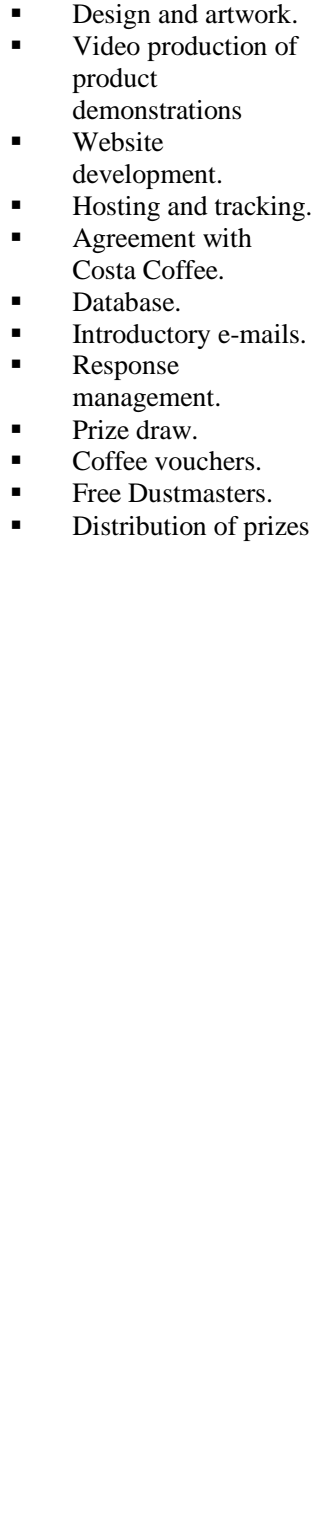 & $\begin{array}{l}\text { To bring the } \\
\text { Flash Easy } \\
\text { Cleaning } \\
\text { Revolution } \\
\text { to life online. } \\
\text { To help } \\
\text { educate } \\
\text { women about } \\
\text { these } \\
\text { revolutionary } \\
\text { products and } \\
\text { demonstrate } \\
\text { how they } \\
\text { could make } \\
\text { cleaning } \\
\text { quicker and } \\
\text { easier. } \\
\text { To convey } \\
\text { the fun and } \\
\text { innovative } \\
\text { Flash } \\
\text { personality }\end{array}$ & $\begin{array}{l}\text { To target } \\
\text { savvy mums } \\
\text { who want to } \\
\text { keep their } \\
\text { homes clean } \\
\text { as } \\
\text { effortlessly } \\
\text { as possible } \\
\text { without } \\
\text { taking } \\
\text { shortcuts. } \\
\text { To } \\
\text { communicate } \\
\text { with the } \\
\text { target } \\
\text { audience via } \\
\text { the internet } \\
\text { identified as } \\
\text { one of their } \\
\text { regular } \\
\text { leisure time } \\
\text { activities. } \\
\text { To make best } \\
\text { use of the } \\
\text { online } \\
\text { medium with } \\
\text { a product } \\
\text { demonstratio } \\
\text { n that not } \\
\text { only } \\
\text { educates } \\
\text { consumers } \\
\text { but also } \\
\text { actively } \\
\text { involves } \\
\text { them in a fun } \\
\text { and engaging } \\
\text { 'virtual trial'. } \\
\text { To raise } \\
\text { awareness of } \\
\text { the site with } \\
\text { an e-mail } \\
\text { campaign } \\
\text { and } \\
\text { incentivise } \\
\text { traffic by } \\
\text { rewarding } \\
\text { participation }\end{array}$ & $\begin{array}{l}\text { 1. Specific results are withheld } \\
\text { at the request of the promoter } \\
\text { The campaign allowed } \\
\text { consumers to interact with the } \\
\text { products in a fun way whilst } \\
\text { still driving the product } \\
\text { benefits. } \\
\text { 3. In the words of one consumer } \\
\text { "...it has to be the best thing } \\
\text { on the internet - ever! } \\
\text { Promotion costs: } \\
\text { 1. } 500 \text { Flash Dustmaster } \\
\quad \text { Extend and Reach } \\
\text { products. } \\
\text { 22 Leisure Vouchers } \\
+ \\
\text { "tools" costs }\end{array}$ & $\begin{array}{l}\text { Competitive } \\
\text { pressure within } \\
\text { household } \\
\text { products is } \\
\text { increasing and } \\
\text { consumers are } \\
\text { confused as to } \\
\text { which product } \\
\text { belongs to which } \\
\text { brand e.g. Flash } \\
\text { Dustmaster vs. } \\
\text { Pledge Dust \&Go } \\
\text { Wipes. } \\
\text { The Flash Easy } \\
\text { Cleaning } \\
\text { Revolution was a } \\
\text { campaign initially } \\
\text { developed as an } \\
\text { experiential } \\
\text { concept to } \\
\text { provide the } \\
\text { products in the } \\
\text { Flash cleaning } \\
\text { portfolio with } \\
\text { common identity } \\
\text { and clear purpose. } \\
\text { Such a campaign } \\
\text { focuson educating } \\
\text { women about } \\
\text { these } \\
\text { revolutionary } \\
\text { products and } \\
\text { demonstrates how } \\
\text { they could make } \\
\text { cleaning quicker } \\
\text { and easier. }\end{array}$ \\
\hline \multicolumn{6}{|c|}{ Case - Promotional message: "Say thank you" (Kimberly-Clark) } \\
\hline
\end{tabular}


Table 4: continued

\begin{tabular}{|c|c|c|c|c|c|}
\hline \multicolumn{6}{|c|}{$\begin{array}{l}\text { Description of the promotion technique: Consumers were invited to collect five Andrex 'Say Thank You' tokens from special promotional } \\
\text { packs. There was one token on } 2 \text {-roll packs, } 2 \text { tokens on } 4 \text {-roll packs and } 4 \text { tokens on } 9 \text {-roll and } 12 \text { for } 9 \text {-roll packs. They then selected the 'thank- } \\
\text { you' gift they would like to give to a family member. The gifts on offer were: } 1 \text {. a book of humorous poems, anecdotes and messages; } 2 \text {. a } \\
\text { manicure, pedicure, a mini makeover, or a mini massage from one of } 300 \text { salons; } 3 \text {. the opportunity to adopt an African elephant, an Orca whale } \\
\text { or a tiger including a donation to the Born Free Foundation; } 4 \text {. a professional photograph of the family from one of } 1,000 \text { studios and } 5 \text {. free days } \\
\text { out for children to over } 300 \text { venues including theme parks, ice skating rinks, museums and wild life centers. The gifts were dispatched together } \\
\text { with a 'thank-you' card and envelope. }\end{array}$} \\
\hline subject & tool & object & goal & result & $\begin{array}{c}\text { Comments } \\
\text { ("Meaning } \\
\text { Perspectives" \& } \\
\text { "Difficulties") }\end{array}$ \\
\hline SMP & $\begin{array}{ll} & \text { Design and artwork. } \\
\text { - } & \text { Print. } \\
& \text { Negotiation with } \\
\text { salons, photographic } \\
\text { studios and child } \\
\text { venues. } \\
\text { Selection and } \\
\text { purchase of } \\
\text { premiums/rewards. } \\
\text { Handling/fulfilment. }\end{array}$ & $\begin{array}{l}\text { To enhance } \\
\text { and endorse } \\
\text { 'Andrex } \\
\text { looking out } \\
\text { for the } \\
\text { family' } \\
\text { whilst } \\
\text { extending the } \\
\text { appeal to a } \\
\text { younger } \\
\text { audience } \\
\text { without } \\
\text { alienating } \\
\text { loyal users } \\
\text { To develop a } \\
\text { campaign } \\
\text { that } \\
\text { delivered } \\
\text { family values } \\
\text { by offering a } \\
\text { choice of } \\
\text { high value, } \\
\text { relevant } \\
\text { rewards with } \\
\text { a minimum } \\
\text { purchase } \\
\text { requirement } \\
\text { To use the } \\
\text { Andrex } \\
\text { Puppy as } \\
\text { facilitator } \\
\text { whilst } \\
\text { appealing to } \\
\text { the widest } \\
\text { audience - } \\
\text { not just } \\
\text { puppy / soft } \\
\text { toy lovers }\end{array}$ & $\begin{array}{l}\text { To target the } \\
\text { activity at all } \\
\text { branded } \\
\text { toilet tissue } \\
\text { purchasers - } \\
\text { especially } \\
\text { younger } \\
\text { Mums with } \\
\text { children at } \\
\text { home. } \\
\text { To deliver a } \\
\text { proposition } \\
\text { that touched } \\
\text { all family } \\
\text { members and } \\
\text { emotionally } \\
\text { motivated } \\
\text { the purchase } \\
\text { of Andrex in } \\
\text { preference to } \\
\text { other } \\
\text { branded } \\
\text { toilet tissues. } \\
\text { To mount an } \\
\text { 'Andrex } \\
\text { ownable' } \\
\text { campaign } \\
\text { that would } \\
\text { set the brand } \\
\text { apart from } \\
\text { the } \\
\text { competition. }\end{array}$ & $\begin{array}{l}\text { 1. Quantified results are } \\
\text { withheld at the request of the } \\
\text { promoter. } \\
\text { Research undertaken during } \\
\text { the promotion indicated that } \\
\text { applications were coming } \\
\text { from a younger and more } \\
\text { affluent audience than Andrex } \\
\text { loyalists generally. } \\
\text { Promotion costs: } \\
\text { 1. Materials } \\
\text { 2. Thank-you cards. } \\
\text { 3. Envelopes. } \\
\text { 4. Vouchers for beauty } \\
\text { treatments and } \\
\text { photographs with lists } \\
\text { of participating salons } \\
\text { / photographers. } \\
\text { 5. Animal adoption } \\
\text { certificates. } \\
\text { 6. Kids Go Free } \\
\text { vouchers. } \\
\text { 7. Family anecdote } \\
\text { books. } \\
\quad \text { "tools" costs }\end{array}$ & $\begin{array}{l}\text { Although the } \\
\text { family remains } \\
\text { the most } \\
\text { important part of } \\
\text { people's lives, its } \\
\text { role is changing. } \\
\text { Britons work the } \\
\text { longest hours in } \\
\text { Europe and } \\
\text { families spend } \\
\text { less quality time } \\
\text { together. Andrex } \\
\text { had a new } \\
\text { positioning - } \\
\text { 'Looking out for } \\
\text { the family' and } \\
\text { needed a } \\
\text { promotion to } \\
\text { enhance this } \\
\text { message and } \\
\text { broaden its } \\
\text { appeal. } \\
\text { Consumers were } \\
\text { given the } \\
\text { opportunity to } \\
\text { 'Say Thank You' } \\
\text { to a special family } \\
\text { member in } \\
\text { appreciation of } \\
\text { his/her support by } \\
\text { sending a free } \\
\text { gift. }\end{array}$ \\
\hline $\begin{array}{l}\text { Sector: Fo } \\
\text { Promotior } \\
\text { Promotior } \\
\text { appeal to 't } \\
\text { Ribenaberı } \\
\text { Promotior } \\
\text { Agency: T } \\
\text { Awards: I } \\
\text { IS }\end{array}$ & $\begin{array}{l}\text { Case - Promotiona } \\
\text { ectives: awareness, trial } \\
\text { tegy: The promotion needed } \\
\text { illd in them'. A fully integrate } \\
\text { as to feature strongly in the pr } \\
\text { iniques: } 1 \text {. Free item - on pac } \\
\text { larketing Store } \\
\text { liver Award winner } 2002 \text { - Pr } \\
\text { onze Award winner } 2002-\mathrm{C}\end{array}$ & $\begin{array}{l}\text { message: "Win cars } \\
\text { communicate with } \\
\text { through the line can } \\
\text { notion. } \\
\text { and 2. Prize promo } \\
\text { notional Communic } \\
\text { ative \& Technical E }\end{array}$ & $\begin{array}{l}\text { that make your dad } \\
\text { his core market (18 } \\
\text { paign was required } \\
\text { lon - instant win } \\
\text { tion Point of Purch } \\
\text { xcellence Premiums }\end{array}$ & $\begin{array}{l}\text { year olds) and provide an irrev } \\
\text { h a strong incentive to purchase }\end{array}$ & $\begin{array}{l}\text { oncept that will } \\
\text { rand equity, }\end{array}$ \\
\hline
\end{tabular}


Table 4: continued

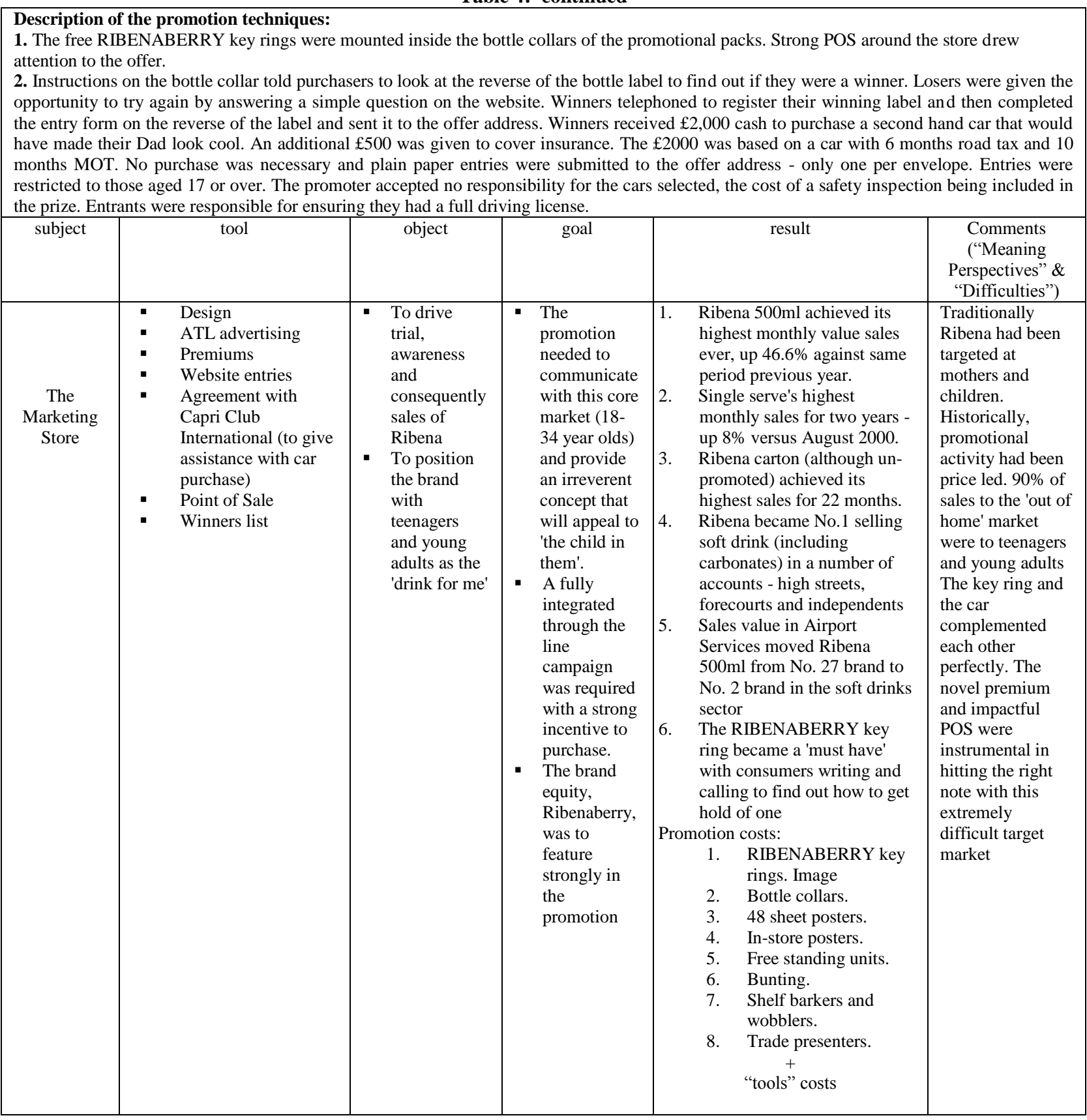

\section{FINDINGS}

Based on the above data analysis of the three (3) critical cases, we present the findings:

- $\quad$ Promotion techniques in all cases were motivated towards transforming the objects into marketing results. In all cases, there was a marketing motive in each promotion activity.

- $\quad$ Promotion techniques shaped the way in which customers acted in all cases. Promotion techniques were shaped by consumers' experience regarding their try to solve information seeking problems. 
- $\quad$ The promotion goals directed systems were adopted where consumers' cognition, behavior, and motivation were integrated and organized by a mechanism of self-regulation toward achieving a conscious goal through the communication of values.

- $\quad$ The marketing results of the promotion activities were those that accomplished the object.

- Promotion techniques were one of the prerequisites for changing consumers' meaning structure. Promotion techniques involved questioning the integrity of a consumer's assumptions and beliefs, which resulted in transformation or changes in a consumer's perspective or engagement of a new behavior.

- Promotion techniques influenced consumers' expectations about the solutions offered by the three organizations framed within their own cultural backgrounds and presuppositions, which directly influenced the meaning derived from personal consumption and product experiences. Promotion techniques encouraged the consumer to examine unfamiliar views, critically reflected and evaluated them, tested and explored new perspectives.

Based on the literature review and the findings from the analysis of the three (3) critical cases, an extension of Bedny's theoretical perspective of activity theory was presented (see Figure 1). The findings seem to confirm the proposed activity system, as a behavioristic framework that can be introduced to aid the design and analysis of promotion techniques. As a conclusion of this section, the findings arisen from: a) the study of international empirical evidence, b) their interpretation (based on the theoretical framework), and c) the analysis of the three (3) critical cases, leaded us to a better understanding of how two influential theories can contribute to the development of a new behavioristic framework, which can be used to aid the design and analysis of promotion techniques. Therefore, the phenomenon studied becomes more visible.

\section{DISCUSSION}

The paper examines the possibility of developing an activity system based on Bedny's representation of Activity Theory incorporating Mezirow's perspective of Transformative Learning Theory (TLT) for Critical Reflection in order to elaborate promotion techniques. The research intention is to examine the possibility to investigate two (2) influential theories: a. Activity Theory and b. TLT in order to develop a new behavioristic framework that could be introduced to aid the design and analysis of promotion techniques by approaching major promotion events of particular interest and with strategic content, as critical cases.

\section{Degree Of Answering The Research Question And The Support Of The Initial Assumptions}

As a conclusion, the findings arisen from: a) the study of international empirical evidence, b) their interpretation (based on the theoretical framework), and c) the analysis of the three (3) critical cases, leaded us to a better understanding of how two influential theories can contribute to the development of a new behavioristic framework. A micro-model that can be introduced to aid the design and analysis of promotion techniques. Based on the above sections, we can accept the initial assumptions that: A) The development of an activity system based on Bedny's representation of Activity Theory incorporating Mezirow's perspective of TLT for Critical Reflection for the elaboration of promotion techniques seems that it can become a new promising theoretical micro-model framework. A new conceptual foundation of consumer responses in the promotion management literature that can suggest determinants of designing and analyzing promotion techniques by approaching major promotion events of particular interest and with strategic content, as critical cases. B) Mezirow's critical reflection can be proven quiet valuable to the proposed behavioristic framework by considering each promotion campaign, as a learning process. Mezirow's reflection in the promotion management context can be considered as a process designed to promote the examination and interpretation of consumers' experience and the promotion of cognitive learning.

\section{Theoretical Implications}

Based on the assumptions of the theoretical framework we can summarize some implications of the underlined theoretical perspectives to our new theoretical model. The development of an activity system based on Bedny's representation of Activity Theory incorporating Mezirow's perspective of TLT for Critical Reflection for the elaboration of promotion techniques seems that it can become a new promising theoretical micro-model framework. A new conceptual foundation of consumer responses in the promotion management literature that can 
suggest determinants of designing and analyzing promotion techniques by approaching major promotion events of particular interest and with strategic content, as critical cases. Mezirow's critical reflection can be proven quiet valuable to the proposed behavioristic framework by considering each promotion campaign, as a learning process. Mezirow's reflection in the promotion management context can be considered as a process designed to promote the examination and interpretation of consumers' experience and the promotion of cognitive learning. The importance of this try arises from the transfer of: i) a psychology theory (Activity Theory); applied in the education practice and ii) an adult learning theory (TLT) to the promotion management context. Learning theories seems that have gained the appropriate focus in the promotion management literature. Quite recently, activity theory seems to gain some focus by marketing scholars.

\section{Practical Implications}

This study offers a perspective of incorporating Mezirow's critical reflection in an activity system, as a new behavioristic framework, which can be used to aid the design and analysis of promotion techniques by approaching major promotion events of particular interest and with strategic content, as critical cases. Mezirow's critical reflection can be proven quiet valuable to the proposed behavioristic framework by considering each promotion campaign, as a learning process. Critical reflection in the promotion management context can be considered as a learning process designed to promote the examination and interpretation of consumers' experience and the promotion of cognitive learning. This argument raises the need to approach each promotion campaign as a critical case. Therefore, each promotion campaign is a critical case in a learning process for promotion managers of becoming critically aware of the practical wisdom of promotion events. Therefore, "phronesis" raises the question whether this concept and the related constructs actually add anything to promotion assumptions and best practices for promotion managers. In accordance to the principles of effective promotion campaign design, implementation, and evaluation, the incorporation of critical reflection in an activity system can serve as an effective framework that can suggest important determinants of promotion campaigns management regarding to the design, analysis of promotion techniques and their effect to consumers' information-seeking behavior through critical reflection driven performance measures.

\section{Further Research}

We would strongly recommend the following in order to deepen our understanding: (i) further theoretical examination of our proposed model under the parameters influencing consumers' information-seeking behavior; (ii) further theoretical examination of our proposed model under the prism of organization's overall marketing planning and (iii) further investigations of our proposed model, examining more real-life critical case studies.

\section{CONCLUSION}

The research aim of the paper was to examine the possibility of developing an activity system based on Bedny's representation of Activity Theory incorporating Mezirow's perspective of TLT for Critical Reflection in order to elaborate promotion techniques. The research intention was to examine the possibility to investigate two (2) influential theories: a. Activity Theory and b. Transformative Learning Theory (TLT) in order to develop a new behavioristic framework, which could be used to aid the design and analysis of promotion techniques by approaching major promotion events of particular interest and with strategic content, as critical cases. First, we attempted to do this by categorizing sixty-eight (68) identified empirical papers into conceptual categories in accordance to the conceptual and theoretical framework. Second, we provided eleven (11) summary points and ten (10) interpretive claims. Third, we examined three (3) critical cases that gave us valuable information. Information on the potentiality of developing an activity system for the design and analysis of promotion techniques and, thus, the phenomenon studied became more visible. We accepted the initial assumptions of this paper that: A) The development of an activity system based on Bedny's representation of Activity Theory incorporating Mezirow's perspective of TLT for Critical Reflection for the elaboration of promotion techniques seems that it could become a new promising theoretical micro-model framework. A new conceptual foundation of consumer responses in the promotion management literature that could suggest determinants of designing and analyzing promotion techniques by approaching major promotion events of particular interest and with strategic content, as critical cases. B) Mezirow's critical reflection could be proven quiet valuable to the proposed behavioristic framework by considering 
each promotion campaign, as a learning process. Mezirow's reflection in the promotion management context could be considered as a process designed to promote the examination and interpretation of consumers' experience and the promotion of cognitive learning.

The development of an activity system based on Bedny's representation of Activity Theory incorporating Mezirow's perspective in order to elaborate promotion techniques showed us that it could become very promising micro-model in the promotion management literature. A systemic examination of both theories in the promotion management field showed us that the new micro-model could offer very significant interpretations and helped us to deepen our understanding for topics related to the assessment and evaluation of promotion campaigns.

\section{ACKNOWLEDGMENT}

I would like to offer my warm thanks to the editors Professor Dean Manna and Professor Mike Budden and the reviewers for their contributory comments.

\section{AUTHOR INFORMATION}

George S. Spais (Ph.D., Panteion University of Social \& Political Sciences, Greece) is an Adjunct Lecturer of Athens University of Economics \& Business (Greece). His research interests are focused on promotion management and marketing education. He is highly interested in promotion management research topics, mostly, related to effectiveness and efficiency of sport sponsorship programs, educational techniques and objectives in marketing education and marketing ideology in the time. He serves as a regional editor (Continental Europe) of the International Electronic Journal for Leadership in Learning and as a member on the editorial boards of (in alphabetical order) Asian Journal of Marketing, Innovative Marketing, International Review of Management, Journal of Business Case Studies, Journal of Marketing Education and Journal of Promotion Management. He is the marketing coeditor of the Journal of Applied Business Research and he is acting as an ad hoc reviewer for several international academic journals and academic conferences. He is a member of the Academy of Marketing Science (USA), the European Marketing Academy of the European Institute for Advanced Studies in Management (Belgium), the Marketing Academy (UK), the EuroMed Academy of Business of the EuroMed Research Business Institute (Cyprus), the Greek Marketing Academy (Greece) and the Hellenic Institute of Marketing (Greece).

\section{REFERENCES}

1. Ahuvia, A. (2005). Beyond the extended self: Loved objects and consumers" identity narratives. Journal of Consumer Research, 32(1), 171-184.

2. Allen, D. (2002). Toward a theory of consumer choice as sociohistorically shaped practical experience: The Fits-Like-a-Glove (FLAG) framework. Journal of Consumer Research, 28(4), 512-533.

3. Andreu, L., Bigne, E., Chumpitaz, R. \& Swaen, V. (2006). How does the perceived retail environment influence consumers' emotional experience? Evidence from two retail settings. International Review of Retail, Distribution and Consumer Research, 16(5), 559-578.

4. Andrews, L., Drennan, J. \& Bennett, R. (2005). Emotions in the experiential consumption of mobile phones. Proceedings of the 2005 Australian and New Zealand Marketing Academy Conference, 18-25. Available: http://smib.vuw.ac.nz:8081/WWW/ANZMAC2005/cd-site/pdfs/12-Electronic-Marketing/12Andrews.pdf

5. Arsel, Z. \& Thompson, C. (2010). Demythologizing consumption practices: How consumers protect their field-dependent identity investments from devaluing marketplace myths. Journal of Consumer Research, DOI: 10.1086/656389 Available: http://zeyneparsel.files.wordpress.com/2010/06/arsel-thompson.pdf

6. Atkin, C. (2001). Theory and principles of media health campaigns. In R. E. Rice \& C. K. Atkin (Eds.), Public communication campaigns (3rd ed., pp. 49-68). Thousand Oaks, CA: Sage.

7. Atkin, C., Hocking, J. \& Block, M. (1984). Teenage drinking: Does advertising make a difference?. Journal of Communication, 34(2), 157-167.

8. Baker, R. \& White, K. (2010). Predicting adolescents' use of social networking sites from an extended theory of planned behaviour perspective. Computers in Human Behavior, 26(6), 1591-1597. 
9. Banna, S., AlKayid, K., Hasan \& Meloche, J. (2009). Usability testing of public health web-based information. Proceedings of the 2009 European and Mediterranean Conference on Information Systems. Available: http://www.iseing.org/emcis/CDROM\%20Proceedings\%20Refereed\%20Papers/Proceedings/NonPresenting\%20Papers/C17/C17.pdf

10. Barr, P., Noble, J., Biddle, R. \& Khaled, R. (2006). From pushing buttons to play and progress: Value and interaction in fable. Proceedings of the Seventh Australasian User Interface Conference (AUIC2006), Conferences in Research and Practice in Information Technology (CRPIT), 50. 61-68. Available: http://crpit.com/confpapers/CRPITV50Barr.pdf

11. Barry, T. and Howard, D. (1990), A review and critique of the hierarchy of effects in advertising. International Journal of Advertising, 9(2), 121-35.

12. Beaudoin, C. (2007). The impact of news use and social capital on youth wellbeing: An aggregate-level analysis. Journal of Community Psychology, 35(8), 947-965.

13. Bedny, G. (2003). Systemic structural theory of activity. In: Wilson, T. (ed.) "A re-examination of information seeking behaviour in the context of activity theory". Information Research, 11, 4, (2006).

Available: http://informationr.net/ir/11-4/paper260.html

14. Bedny, G., Seglin, M. and Meister, D. (2000). Activity theory: history, research and application. Theoretical Issues in Ergonomic Science, 1(2), 168-206.

15. Berger, J. \& Heath, C. (2007). Where consumers diverge from others: Identity-signaling and product domains. Journal of Consumer Research, 34(2), 121-134.

16. Berger, J. \& Heath, C. (2008). Who drives divergence? Identity-signaling, outgroup dissimilarity and the abandonment of cultural tastes. Journal of Personality and Social Psychology, 95(3), 593-607.

17. Berry, T., Spence, J., Plotnikoff, R., Bauman, A., McCargar, L., Witcher, C., Clark, M., \& Stolp, S. (2009). A mixed methods evaluation of televised health promotion advertisements targeted at older adults. Evaluation and Program. Planning, 32(3), 278 - 288.

18. Bertelsen, O. \& Godsk, M. (2004). WAW: An activity theory based tool for early website usability assessment. International Journal of Human Resources Development and Management, 4(1), 73-93.

19. Bertilsson, J. (2007). The enculturation of young consumers: Young peoples "dealings with the logic of brands and branding. Proceedings of the 2007 Nordic Consumer Policy Research Conference. Available: http://www.consumer2007.info/wp-content/uploads/children2-\%20Bertilsson.pdf

20. Bettman, J. (1979). Information Processing Theory of consumer choice. Massachusetts: Addison-Wesley Educational Publishers Inc.

21. Bigné, J., Aldás-Manzano, J., Küster, I. \& Vila, N. (2002). The concept mapping approach in marketing: An application in the travel agencies sector. Qualitative Market Research, 5(2), 87-95.

22. Blackler, F. \& Regan, S. (2009). Intentionality, agency, change: Practice theory and management. Management Learning, 40(2), 161-176.

23. Bobkowskia, P. (2009). Adolescent religiosity and selective exposure to television. Journal of Media and Religion, 8(1), 55-70.

24. Booth-Butterfield, S. \& Reger, B. (2004). The message changes belief and the rest is theory: The " $1 \%$ or less" milk campaign and reasoned action. Preventive Medicine, 39(3), 581-588.

25. Brekke, K. \& Rege, M. (2007). Advertising as a distortion of social learning. B.E. Journal of Theoretical Economics 7(1). Available: http://www.bepress.com/bejte/vol7/iss1/art38

26. Brown, C., Holmes, S. \& Pan, R. (2005). Victims of marketing: Consumers' lived experiences. Proceedings of the 2005 Australian and New Zealand Marketing Academy Conference Available: http://smib.vuw.ac.nz:8081/WWW/ANZMAC2005/cd-site/pdfs/3-Consumer-Beh/3-Brown_Holmes.pdf

27. Brown, J., Steele, J., \& Walsh-Childers, K. (2002). Introduction and overview. In J. D. Brown, J. R. Steele \& K.Walsh-Childers (Eds.) Sexual teens, sexual media: Investigating media's influence on adolescent sexuality (pp. 1-24). Mahwah, NJ: Lawrence Erlbaum Associates, Inc.

28. Cameron, K. \& Campo, S. (2006). Stepping back from social norms campaigns: Comparing normative influences to other predictors of health behaviors. Health Communication, 20(3), 277-288.

29. Chandran, S. \& Morwitz, V. (2005). Effects of participative pricing on consumers ${ }^{\text {ee }}$ cognitions and actions: A goal theoretic perspective. Journal of Consumer Research, 32(2), 249-259. 
30. Cherrier, H. \& Lego Munoz, C. (2007). A reflection on consumers' happiness: The relevance of care for others, spiritual reflection, and financial detachment. Journal of Research for Consumers, 12. Available: http://www.jrconsumers.com/_data/page/4484/CherrierMunoz_academic version.pdf

31. Childers, T. \& Houston, M. (1984). Conditions for a picture-superiority effect on consumer memory. Journal of Consumer Research, 11(2), 643-654.

32. Chintagunta, P. \& Rao, P. (1996). Pricing strategies in a dynamic duopoly: A differential game model. Management Science, 42(11), 1501-1514.

33. Christ, P. (2007). "Internet technologies and trends transforming public relations". Journal of Website Promotion, 1(4), 3-14.

34. Clarke, I., Kell, I., Schmidt, R. \& Vignali, C. (1998). Thinking the thoughts they do: Symbolism and meaning in the consumer experience of the "British pub". Qualitative Market Research, 1(3), 132-144.

35. Coen, M. (1998). Design principles for intelligent environments. Proceedings of AAAI Spring Symposium on Intelligent Environment. Available: http://people.csail.mit.edu/mhcoen/Papers/aaai98.pdf

36. Cohen, E., Shumate, M. \& Gold, A. (2007). Anti-smoking media campaign messages: Theory and practice. Health Communication, 22(2), 91-102

37. Cohena, E., Shumateb, M. \& Goldc, A. (2007). Anti-smoking media campaign messages: Theory and practice. Health Communication, 22(2), 91-102.

38. Cowley E. (2008). Looking back at an experience through rose-colored glasses. Journal of Business Research, 61(10), 1046-1052.

39. Craig, C., Bauman, A. \& Reger-Nash, B. (2010). Testing the hierarchy of effects model: ParticipACTION's serial mass communication campaigns on physical activity in Canada Health Promotion International, 25(1), 14-23.

40. Cutler, A. (2004). Methodical failure: the use of case study method by public relations researchers. Public Relations Review, 30(3), 365-375.

41. Daugherty, T. \& Reece, B. (2002). The adoption of persuasive internet communication in advertising and public relations curricula. Journal of Interactive Advertising, 3(1). Available: http://jiad.org/article29

42. Davies, A. \& and Cline, T. (2005). A consumer behavior approach to modeling monopolistic competition. Journal of Economic Psychology, 26(6), 797-826.

43. Dearing, J. (2008). Evolution of diffusion and dissemination theory. Journal of Public Health Management Practice, 14(2), 99-108.

44. Deighton, J. \& Schindler, R. (1988). Can advertising influence experience?. Psychology and Marketing, 5(2), 103-115.

45. Desmet, P. \& Hekkert, P. (2007). Framework of product experience. International Journal of Design, 1(1), 57-66.

46. Doniger, A., Adams, E., Utter, C. \& Riley, J. (2001). Impact evaluation of the "not me, not now" abstinence-oriented, adolescent pregnancy prevention communications program, Monroe County, New York. Journal of Health Communication, 6(1), 45-60.

47. Fabiano, P., Perkins, H., Berkowitz, A., Linkenbach, J. \& Stark, C. (2003) Engaging men as social justice allies in ending violence against women: Evidence for a social norms approach. Journal American College Health, 52(3), 105-112.

48. Ferreira, P., Zdunczyk, K. \& Simpson, A. (2010). Knowing marketing: An activity theory perspective on knowledge and learning in the marketing domain. Proceedings of the 2010 International Conference Organizational Learning.

Available:http://cba.neu.edu/uploadedFiles/Site_Sections/OLKC_2010/Program_Overview/Parallel_Sessio ns/214_Ferreira Full\%20Paper 320_Knowing\%20Marketing.pdf

49. Festinger, L. (1957). A theory of cognitive dissonance. Stanford, CA: Stanford University Press.

50. Fitzsimons, G., Nunes, J. \& Williams, P. (2007). License to sin: The liberating role of reporting expectations. Journal of Consumer Research, 34(1), 22-31.

51. Fjed, M., Lauche, K., Bichsel, M., Voorhorst, F., Krueger, H. \& Rauterberg, M. (2002). Physical and virtual tools: Activity theory applied to the design of groupware. Computer Supported Cooperative Work 11(1), 153-180.

52. $\quad$ Flyvbjerg, B. (2006). Five misunderstandings about case-study research. Qualitative Inquiry, 12(2), 219245. Available: http://flyvbjerg.plan.aau.dk/Publications2006/0604FIVEMISPUBL2006.pdf. 
53. Frambach, R., Roest, H. \& Krishnan, T. (2007). The impact of consumer internet experience on channel preference and usage intentions across the different stages of the buying process. Journal of Interactive Marketing, 21(2), 26-41.

54. Gadish, D. (2008). Promoting online sales of dental supplies on a tight budget. Journal of Website Promotion, 3(3), 183-195.

55. Green, D. (2003). Search Engine Marketing: Why it benefits us all. Business Information Review, 20(4), 195-202.

56. Green, E. \& Witte, K. (2006). Can fear arousal in public health campaigns contribute to the decline of HIV prevalence?. Journal of Health Communication, 11(3), 245-259.

57. Hansen, T., Thomsen, T., Beckmann, S. \& Boye, H. (2009). Consumers' health information seeking behaviour in the food market. Proceedings of ANZMAC 2009. Available: http://www.duplication.net.au/ANZMAC09/papers/ANZMAC2009-296.pdf

58. Ho, T. \& Chong J. (2003). A parsimonious model of stock-keeping unit choice. Journal of Marketing Research, 40(3), 351-365.

59. Hoch, S. (2002). Product experience is seductive. Journal of Consumer Research, 29(3), 448-454.

60. Holbrook, M. (2006). Consumption experience, customer value, and subjective personal introspection: An illustrative photographic essay. Journal of Business Research, 59(6), 714-725.

61. Hui, M. \& Bateson, J. (1991). Perceived control and the effects of crowding and consumer choice on the service experience. Journal of Consumer Research, 18(2), 174-184.

62. Hwanga, Y. (2010). Selective exposure and selective perception of anti-tobacco campaign messages: The impacts of campaign exposure on selective perception. Health Communication, 25(2), 182-190.

63. Johnson, C. \& Mathews, B. (1997). The influence of experience on service expectations. International Journal of Service Industry Management, 8(4), 290-305.

64. Kangun, N. (1968). How advertisers can use learning theory: Mass marketing requires mass communications. Business Horizons 11(2), 29-40.

65. Kennedy, K. and Kennedy, B. (2008). A small company's dilemma: using search engines effectively for corporate sales. Management Research News, 31(10), 737-745.

66. Kim J-Y, Natter, M. \& Spann, M. (2009). Pay what you want: A new participative pricing mechanism. Journal of Marketing, 73(1), 44-58.

67. Kitchener, K., \& King, P. (1990). The reflective judgment model: Transforming assumptions about knowledge. In: J. Mezirow \& Associates (eds.), Fostering critical reflection in adulthood: A guide to transformative and emancipatory learning (pp. 159-176). San Francisco: Jossey-Bass.

68. Knouse, S. (1986). Brand loyalty and sequential learning theory. Psychology and Marketing, 3(2), 87-98.

69. Kohlbacher, F. (2006). The use of qualitative content analysis in case study research. Forum Qualitative Sozialforschung / Forum: Qualitative Social Research, 7(1). Available: http://www.qualitativeresearch.net/index.php/fqs/article/view/75/154

70. Kotler, P. \& Roberto, E. (1989). Social marketing. New York: The Free Press.

71. Kozinets, R. (2001). Utopian enterprise: Articulating the meaning of Star Trek's culture of consumption. Journal of Consumer Research, 28(1), 67-89.

72. Krugman, H. (1962a). The learning of consumer preference. Journal of Marketing, 26(2), 31-33.

73. Krugman, H. (1962b). An application of learning theory to tv copy testing. Public Opinion Quarterly 26(4), 626-634.

74. Krugman, H. \& Hartley, E. (1970). Passive learning from television. Public Opinion Quarterly, 34(2), 184190.

75. Kwortnik, R. \& Ross, W. (2007). The role of positive emotions in experiential decisions. International Journal of Research in Marketing, 24(4), 324-336.

76. Lin, C., Lin, J. \& Wu, S. (2008). Exploring consumers' keyword ads search behaviors: An integration of Theory of Planned Behavior and Flow Theory. PACIS 2008 Proceedings. paper 207. Available: http://aisel.aisnet.org/pacis2008/207

77. Lutze, H. (2008). An introduction to using keywords in paid search campaigns. Search Engine Marketing Journal 1, suppl. issue. Available: http://www.semj.org/documents/SEMJ_2008_supplemental.pdf.

78. Maddock, J., Silbanuz, A. \& Reger-Nash, B. (2008).Formative research to develop a mass media campaign to increase physical activity and nutrition in a multiethnic state. Journal of Health Communication, 13(3), 208-215. 
79. McAlister, A., Morrison, T., Hu, S., Meshack, A., Ramirez, A., Gallion, K., Rabius, V., \& Huang, P. (2004). Media and community campaign effects on adult tobacco use in Texas. Journal of Health Communication, 9(2), 95-109.

80. McCullough, M. (2007). New media urbanism: grounding ambient information technology. Environment and Planning B: Planning and Design, 34(3), 383 - 395.

81. McKay, A. (2005). The practice of advertising, 5th Edition. Oxford: Elsevier Butterworth Heinemann.

82. McGregor, S. (2007). Sustainability through vicarious learning: Reframing consumer education. In: A. Wals (ed.), Social learning towards a more sustainable world: Principles, perspectives and praxis (pp. 351-368). Wageningen, the Netherlands: Wageningen Academic Publishers.

83. McGregor, S. (2009). Reorienting consumer education using social learning theory: Sustainable development via an authentic consumer pedagogy. International Journal of Consumer Studies, 33(2), 258266.

84. McKee, D., Conant, J., Varadarajan, P. \& Mokwa, M. (1992). Success-producer and failure-preventer marketing skills: A social learning theory interpretation. Journal of the Academy of Marketing Science, 20(1), 17-26.

85. McLarney, C. \& Chung, E. (1999). Post-materialism's "silent revolution" in consumer research. Marketing Intelligence \& Planning, 17(6), $288-297$.

86. McMahon, D. and Griffy-Brown, C. (2009). Developing an effective and affordable search engine marketing strategy for nonprofits. International Journal of Internet Marketing and Advertising, 5(1), 113130 .

87. Merskin, D. (2008). Race and gender representations in advertising in cable cartoon programming. CLCWeb: Comparative Literature and Culture, 10(2). Available: http://docs.lib.purdue.edu/clcweb/vol10/iss2/10

88. Mezirow, J. (1978). Perspective transformation. Adult Education, 28(2), 100-110.

89. Mezirow, J. (1990). How critical reflection triggers transformative learning. In: Mezirow, J., \& Associates (eds.), Fostering critical reflection in adulthood: A guide to transformative and emancipatory learning. San Francisco: Jossey-Bass.

90. Mezirow, J. (1991).Transformative dimensions of adult learning. San Francisco, CA: Jossey-Bass.

91. Mezirow, J. (1998). On critical reflection. Adult Education Quarterly, 48(3), 185-198.

92. Mezirow, J. (2000). Learning as transformation: Critical perspectives on a theory in progress. San Francisco: Jossey Bass.

93. Mezirow, J. (2003). Transformative learning as discourse. Journal of Transformative Education, 1(1), 5863.

94. Montgomery, H., Sharafi, P. and Hedman, L. (2004). Engaging in activities involving information technology: Dimensions, modes, and flow. Human Factors, 46(2), 334-348.

95. Mooy, S. \& Robben, H. (2002). Managing consumers' product evaluations through direct product experience. Journal of Product \& Brand Management, 11(7), 432-446.

96. Murphy, H. and Kielgast, C. (2008). "Do small and medium-sized hotels exploit search engine marketing?”. International Journal of Contemporary Hospitality Management, 20(1), 90-97.

97. Mursu, A., Luukkonen, I., Toivanen, M. and Korpela, M. (2007). Activity theory in information systems research and practice: Theoretical underpinnings for an information systems development model. Information Research, 12(3). Available: http://informationr.net/ir/12-3/paper311.html.

98. Noar, S. (2006). A 10-year retrospective of research in health mass media campaigns: Where do we go from here?. Journal of Health Communication, 11(1), 21-42.

99. Novemsky, N. \& Ratner, R. (2003). The time course and impact of consumers' erroneous beliefs about hedonic contrast effects. Journal of Consumer Research, 29(4), 507-516.

100. O'Brien, H. \& Toms, E. (2007). Evaluating engagement in interactive search. SIGIR 2007 Workshop Web Information Seeking and Interaction $-30^{\text {th }}$ Annual International ACM SIGIR Conference. Available: http://research.microsoft.com/en-us/um/people/ryenw/proceedings/WISI2007.pdf

101. Ofir, C. \& Simonson, I. (2001). In search of negative customer feedback: The effect of expecting to evaluate on satisfaction evaluations, Journal of Marketing Research, 38(2), 170-182

102. Ölander, F. (1977). Can consumer dissatisfaction and complaints guide public consumer policy?. Journal of Consumer Policy, 1(2), 124-137. 
103. Oldenburg, B., Hardcastle, D. \& Kok, G. (1997). Diffusion of innovations. In K. Glanz, F.M. Lewis \& B.K. Rimer (Eds.), Health behavior and health education (2nd ed., pp.270-286), San Francisco: Jossey-Bass Publishers.

104. O’Sullivan, E. (2003). Bringing a perspective of transformative learning to globalized consumption. International Journal of Consumer Studies 27(4), 326-330.

105. Pardun, C., L'Engle, K. \& Brown, J. (2005). Linking exposure to outcomes: Early adolescents' consumption of sexual content in six media. Mass Communication \& Society, 8(2), 75-91.

106. Park, C., Feick, L. \& Mothersbaugh, D. (1992). Consumer knowledge assessment: How product experience and knowledge of brands, attributes and features affects what we think we know. Advances in Consumer Research, 19(3), 193-198.

107. Pechmann, C. \& Wang, L. (2010). Effects of indirectly and directly competing reference group messages and persuasion knowledge: Implications for educational placements. Journal of Marketing Research, 47(1), 134-145.

108. Pelling, E. \& White, K. (2009). The Theory of Planned Behavior applied to young people's use of social networking web sites. Cyberpsychology and Behavior, 12(6), 755-759.

109. Penz, E. (2006). Researching the socio-cultural context: Putting social representations theory into action. International Marketing Review, 23(4), 418-437.

110. Perloff, R. (2003). The dynamics of persuasion: Communication and attitudes in the 21st century. (2nd ed.). Mahwah, NJ: Lawrence Erlbaum.

111. Petrova, P. \& Cialdini, R. (2005). Fluency of consumption imagery and the backfire effects of imagery appeals. Journal of Consumer Research, 32(3), 442-452.

112. Randolph, W. \& Viswanath, K. (2004). Lessons learned from public health mass media campaigns: Marketing health in a crowded media world. Annual Review of Public Health, 25, 419-37.

113. Renger, R., Steinfelt, V. \& Lazarus, S. (2002). Assessing the effectiveness of a community based media campaign targeting physical inactivity. Family and Community Health, 25(3), 18-30.

114. Richins, M. (1997). Measuring emotions in the consumption experience. Journal of Consumer Research, 24(2), 127-146.

115. Rimbach, F., Dannenberg, M. and Bleimann, U. (2007). Page ranking and topic-sensitive page ranking: micro-changes and macro-impact. Internet Research, 17(1), 38-48.

116. Roberto, A., Meyer, G., Johnson, A. \& Atkin, C. (2000). Using the parallel process model to prevent firearm injury and death: field experiment results of a video-based intervention. Journal of Communication, 50(4), 157-175.

117. Rogers, E. (1983). Diffusion of innovations. New York: The Free Press.

118. Rogers, E. \& Storey, J. (1987). Communication campaigns. In C. R. Berger \& S. H. Chafee (Eds.), Handbook of communication science (pp. 817-846). London: Sage.

119. Rothschild, M. (1981). Providing reinforcers for environmentally unconcerned consumers. Advances in Consumer Research, 8(1), 642-643.

120. Rothschild, M. \& Gaidis, W. (1981). Behavioral learning theory: Its relevance to marketing and promotions. Journal of Marketing 45(3), 70-78.

121. Salmon, C. \& Atkin, C. (2003). Using media campaigns for health promotion. In T. L. Thompson, A. M. Dorsey, K. I. Miller, \& R. Parrott (Eds.), Handbook of Health Communication (pp. 285-313). Mahwah, NJ: Lawrence Erlbaum.

122. Schmalensee, R. (1978). A model of advertising and product quality. Journal of Political Economy 86(3), 485-503.

123. Smallwood, D. \& Conlisk, J. (1979). Product quality in markets where consumers are imperfectly informed. Quarterly Journal of Economics, 93(1), 1-23.

124. Smith, A. (2007). Exploring advergaming and its online advertising implications. International Journal of Business Information Systems, 2(3), 298-311.

125. Soutar, G. \& Sweeney, J. (2003). Are there cognitive dissonance segments?. Australian Journal of Management, 28(3), 227-249.

126. Spais, G. (2010a). Search Engine Optimization (SEO) as a dynamic online promotion technique: The implications of activity theory for promotion managers. Innovative Marketing, 6(1), 7-24. 
127. Spais, G. (2010b). Promotion metrics' assumptions for the assessment and evaluation of promotion campaigns: A framework based on Mezirow's critical reflection. Journal of Applied Business Research, 26(2), 23-46.

128. Spais, G. (2010c). Strengthening event study methodology to the promotion management field based on Flyvbjerg's methodological guidelines on critical case study. Innovative Marketing, 6(3), 8-32.

129. Stake, R. (1994). Case Studies. In N. Denzin \& Y. Lincoln (Eds.) Handbook of Qualitative Research. Thousand Oaks, CA: Sage Publications.

130. Stead, M., Tagg, S., MacKintosh, A. \& Eadie, D. (2005). Development and evaluation of a mass media Theory of Planned Behaviour intervention to reduce speeding. Health Education Research, 20(1), 36-50.

131. Suh. K., Couchman, P., Park, J. and Hasan, H. (2003). The application of activity theory to web-mediated communication. In H. Hasan, I. Verenikina, I. \& E. Gould (eds.) Information systems and activity theory volume 3: Expanding the horizon. Wollongong, Australia: University of Wollongong Press. Available: http://www.syros.aegean.gr/users/tsp/citations_dnl/ATIS3_Chapter6.pdf.

132. Tan, S. \& Melles, G. (2010). An activity theory focused case study of graphic designers' tool-mediated activities during the conceptual design phase. Design Studies, 31(5), 461-478.

133. Tan, T \& Uncles, M. (2008). Corporate social responsibility as an advertising appeal. Proceedings of the 2008 Australian and New Zealand Marketing Academy Conference.

134. Taylor, E. (1998). The theory and practice of transformative learning: A critical review. Information Series No.374 Columbus: ERIC Clearinghouse on Adult, Career, and Vocational Education, Center on Education and Training for Employment, College of Education, the Ohio State University.

135. Thelwall, M. (2001). Commercial web site links. Internet Research, 11(2), 114-124.

136. Thombs, D. \& Hamilton, M. (2002). Effects of a social norm feedback campaign on the drinking norms and behavior of division 1 student-athletes. Journal of Drug Education, 32(3), 227-244.

137. Thompson, C. \& Haytko, D. (1997). Speaking of fashion: Consumers' uses of fashion discourses and the appropriation of countervailing cultural meanings. Journal of Consumer Research, 24(1), 15-42.

138. Thompson, C., Locander, W. \& and Pollio, H. (1989). Putting consumer experience back into consumer research: The philosophy and method of existential-phenomenology. Journal of Consumer Research, 16(2), 133-146.

139. Thorson, E. \& Beaudoin, C. (2004). The impact of a health campaign on health social capital. Journal of Health Communication, 9(3), 167-194.

140. Uden, L., Valders, P. \& Pastor, O. (2008). An activity-theory-based model to analyse web application requirements". Information Research, 13(2). Available: http://informationr.net/ir/13-2/paper340.html.

141. Uden, L. \& Willis, N. (2001). Designing user interfaces using activity theory. Proceedings of the 34th Annual Hawaii International Conference on System Sciences, 5, 5031-5042.

142. Valente, T. (2001). Evaluating communication campaigns. In R. E. Rice \& C. K. Atkin (Eds.), Public communication campaigns (3rd ed., pp. 105-124). Thousand Oaks, CA: Sage.

143. Vaughan, P., Rogers, E., Singhal, A. \& Swalehe, R. (2000). Entertainment education and HIV/AIDS prevention: A field experiment in Tanzania. Journal of Health Communication, 5(3), 81-101.

144. Vida, I. (2007). Determinants of consumer willingness to purchase non-deceptive counterfeit products. Managing Global Transitions, 5(3), 253-270.

145. Wilson, T. (2006). A re-examination of information seeking behaviour in the context of activity theory. Information Research, 11(4). Available: http://informationr.net/ir/11-4/paper260.html

146. Wilson, T. (2008). Activity theory and information seeking. Annual Review of Information Science and Technology, 42(1), 119-161.

147. Witte, K., Cameron, K. Lapinski, M. \& Nzyuko, S. (1998). A theoretically based evaluation of HIV/AIDS prevention campaigns along the transAfrica highway in Kenya. Journal of Health Communication, 3(4), $345-367$.

148. Wooten, D. \& Reed II, A. (1998). Informational influence and the ambiguity of product experience: Order effects on the weighting of evidence. Journal of Consumer Psychology, 7(1), 79-99.

149. Xu, Y. (2007). The dynamics of interactive information retrieval behavior, Part I: An activity theory perspective. Journal of the American Society for Information Science and Technology, 58(7), 958-970.

150. Yin, R. (1994). Case study research: Design and methods (2nd ed.). Thousand Oaks, CA: Sage Publications. 
151. Yoon, C., Cole, C. \& Lee, M. (2009). Consumer decision making and aging: Current knowledge and future directions. Journal of Consumer Psychology, 19(1), 2-16.

152. Young, K. (2009). Online social networking: An Australian perspective. International Journal of Emerging Technologies and Society, 7(1), 39-57. Available:

http://www.swinburne.edu.au/hosting/ijets/journal/V7N1/pdf/Article4Young.pdf

153. Yucha, M. \& Sasi, S. (2005). An abstract content-based image retrieval system based on activity theory. Proceedings of the 2005 IEEE Pacific Rim Conference on Communications, Computers and Signal Processing, 574- 577. 
NOTES 